\title{
INNOVATION, SPATIAL LOYALTY, AND ICTS AS LOCATIONAL DETERMINANTS OF RURAL DEVELOPMENT IN THE CATALAN PYRENEES
}

\author{
Ana Vera Martin ${ }^{1}$ and Antoni F. Tulla ${ }^{2}$
}

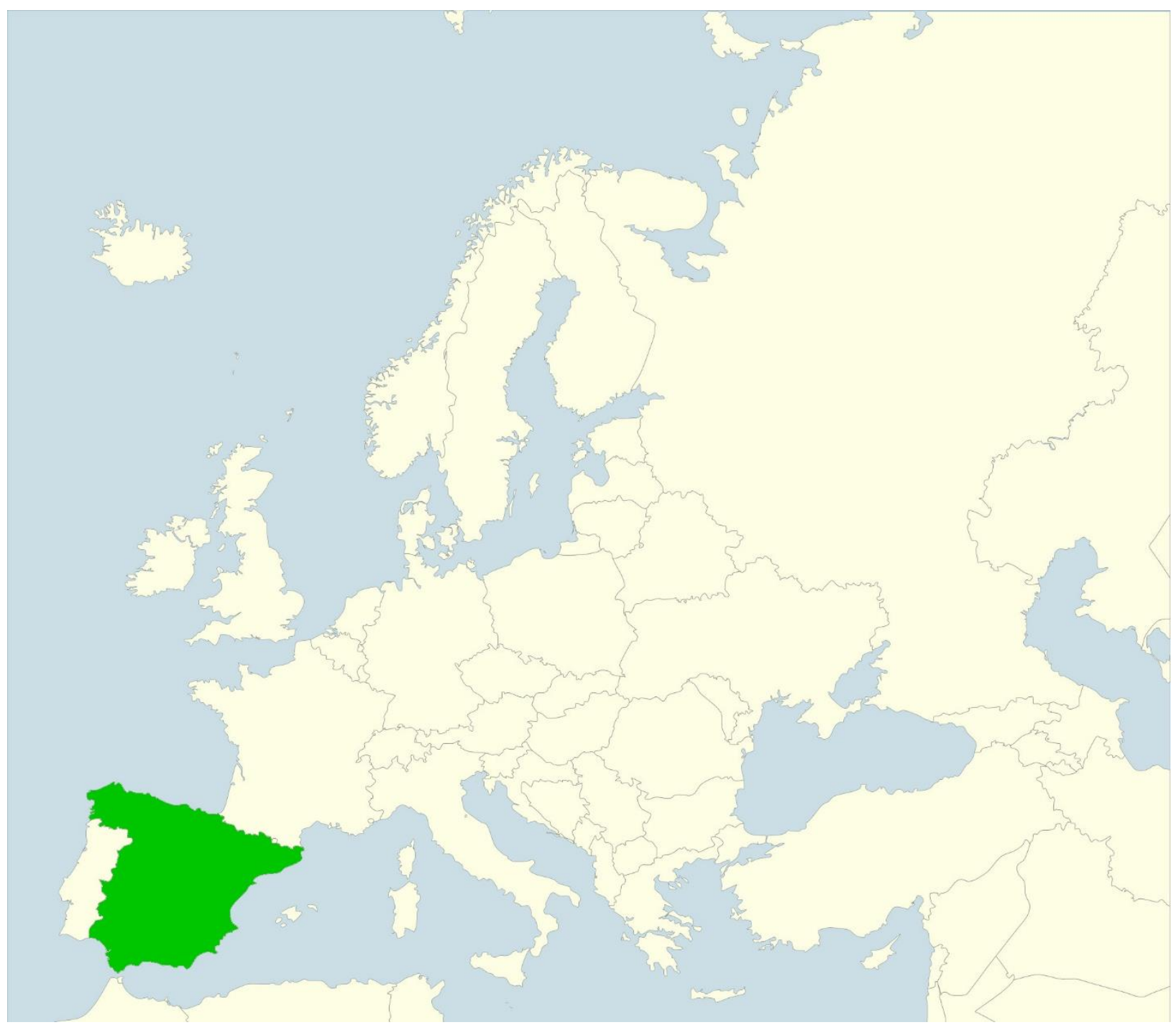

1 Lecturer in the Geography Department of the Universitat Autònoma de Barcelona Bellaterra (Spain); Ana.vera@uab.cat. ORCID: 0000-0001-7865-1610.

2 Emeritus Professor at the Geography Department of the Universitat Autònoma de Barcelona, Bellaterra (Spain); Antoni.tulla@uab.cat. ORCID: 0000-0003-0937-3252. 
Abstract: Information and communication technologies (ICTs) open up new possibilities for development in rural and mountain areas. ICTs are analysed as a factor attracting business and enabling a dispersion of economic activity that is usually concentrated in metropolitan areas. Rural and mountain areas have benefited from the increasing incorporation of ICT in companies because development strategies are now made viable, thus bringing local territories into global markets and vice versa. Competitiveness and the added value of local development companies are incorporated into the product through the value given to local identity factors. Other competitive localisation factors of these zones are lower localisation costs and spatial loyalty among companies in the cluster. On the other hand, there may be an a priori shortage of available skilled workers in these particular areas but this deficit could be balanced out by the small size of companies established in these zones. This paper describes several case studies of specific companies in the Catalan Pyrenees where parts of the productive process with the highest added value-like design, organisation, etc-are carried out, while manufacturing occurs in other countries. It also analyses activities and services offered by smart farms and in smart rural areas. ICTs are important for the educational and informative levels of the population and also for the establishment of new companies and services in rural and mountain areas.

Keywords: Catalan Pyrenees, Innovation, Localization factors, Rural development, Smart rural areas, Spatial Loyalty, ICTs.

Resum: Innovació, lleialtat espacial i TICs com a determinants de la localització en el desenvolupament rural del Pirineu català. Les tecnologies de la informació i la comunicació (TIC) obren noves possibilitats de desenvolupament en zones rurals i de muntanya. S'analitza les TIC com a factor d'atracció de negoci; i que facilita una dispersió de l'activitat econòmica, generalment concentrada en les àrees metropolitanes. Aquestes zones rurals i de muntanya s'han beneficiat de la incorporació creixent de les TIC a les empreses, atès que aquest procés promou estratègies de desenvolupament viables, portant els territoris locals als mercats globals i viceversa. La competitivitat i el valor afegit de les empreses de desenvolupament local s'incorporen al producte amb la valorització d'aquests factors d'identitat locals. Altres factors de localització competitius d'aquestes zones són uns costos de localització menor així com la lleialtat espacial entre les empreses del clúster. D'altra banda, pot haver-hi una escassetat de treballadors qualificats que difícilment estaran disponibles a priori en aquestes àrees específiques. Dèficit que es pot compensar per la petita dimensió de les empreses ubicades en aquestes zones. és pretén explicar alguns casos específics d'empreses del Pirineu català, on hi realitzen algunes parts del procés productiu amb més valor afegit (disseny, organització, etc.) mentre que la fabricació es troba en altres països amb salaris més baixos. També s'analitzen algunes activitats i serveis que generen explotacions agràries i territoris rurals intel-ligents. Llavors, les TIC són importants per al nivell educatiu i informatiu de la població i per a la instal-lació de noves empreses a les zones rurals i de muntanya.

Paraules clau: Desenvolupament rural, Factors de localització, Innovació, Lleialtat espacial, Pirineus catalans, Territoris rurals intel-ligents, TIC.

\section{Introduction}

The twenty-first century has brought continuous advances in information and communication technologies (ICTs), first in urban areas and subsequently in rural areas. In the latter, the effects of the new technologies have been more resounding because of longstanding problems of 
accessibility, low population density, and distance from urban and industrial centres (Malecki, 2003). Without a doubt, ICTs are part of innovation in both production and distribution of goods and services, although the most important advance has been the creation of intelligent territories.

In this article, we describe how the use of ICTs in rural areas favours the creation of added value in economic activities without having undesirable effects in the environment or the landscape and, as a result, promoting local sustainable development. We have found that three different but complementary results have appeared in this process of innovation using ICTs. First, it favours the localisation of new businesses which do not depend on economies of agglomeration, for example, companies producing textiles for sports clothing. Second, the computerisation of rural, basically agrarian activities allows for easier management and also better coordination within clusters, for example in the production and transportation of milk. Third and finally, this process encourages the establishment of an intelligent rural community which strengthens people's relations with services by means of digital platforms such as those offering transport on demand or programming cultural activities (Philip and Williams, 2019).

It has been possible to confirm that the development of ICTs is clearly a process of diffusion (Hägerstrand, 1965), starting with pioneering companies in urban and metropolitan areas, gradually extending into market towns in rural areas, and eventually reaching the more peripheral zones of mountain regions. This concept of diffusion can also be applied to innovation in dairy farms of the Catalan Pyrenees (Tulla, 1983) where a clearly visible original innovating group is followed by incorporation of some of the other farms in different phases. A similar process also applies to the incorporation of robots and various kinds of ICTs in dairy farms of the La Cerdanya and Alt Urgell districts (Mármol Cartañá, 2016).

This study aims to present evidence of the introduction of ICTs in rural mountain areas of the High Pyrenees and Aran (HP\&A) region. ${ }^{3}$ However, we shall first describe the model applying to Catalonia as a whole, although our chief interest is expansion to peripheral areas. In general, the economic system and factors of company localisation have been evolving with the use of new ICTs. These changes in the structure of businesses have conditioned their capacity to store, analyse, and instantly communicate information anywhere and at minimal cost. Meanwhile, interaction with the demand has grown, transport costs have been rationalised, and the impact of efficiencies achieved in economies of scale has lessened.

The new economic system is identified by means of three basic elements (Kelly, 1998). Firstly, it is the global aspect referring to production and distribution of markets; secondly, is the establishment of networking; and, last but not least, is the flow of intangible elements like ideas, information, and relations. These three factors show that, for businesses of the new economy, management of $R+I_{+} D^{4}$, design, and time to market (TTM) are the most important factors (Blanco, 2004) and they are based on the speed at which exchanges take place in a delocalised, flexible productive system, and innovation in services and manufacture (Knox, 2003).

Our main objective is to analyse the importance of ICTs as a factor of sustainable development in HP\&A, Catalonia's most mountainous region. We shall briefly present the area under study and describe the conceptual framework and methodology used. This will be followed by discussion of the three blocks of cases analysed and, finally, an account of the results obtained together with our final conclusions.

\section{The High Pyrenees and Aran (HP\&A) as an area of study}

In terms of distances from urban centres of Catalonia, HP\&A (Fig. 1) is an especially remote region where a centuries-old lifestyle based on agricultural self-sufficiency gave way some decades ago to tourism and, in some cases, competitive livestock farming (Barrachina, 2010).

\footnotetext{
${ }^{3}$ Law 23/1983 on Territorial Policy (Art. 12) and Law 1/1995 on the General Territorial Plan of Catalonia (Art. 2) delimit planning regions by producing partial territorial plans such as those for HP\&A.

${ }^{4}$ Research, Innovation and Development.
} 
Transformation of the primary sector has occurred either by means of investment in technology or incorporating added value into production and, in some cases, a combination of both (Tulla, 2009; Pallarès-Blanch, 2015). Nevertheless, the main economic activities nowadays are services, as has happened elsewhere in most so-called "rural consumption" areas of Europe (Copus, 2006, Noguera, 2016), a sector with the greatest concentration of women employed in remunerated work (Bock, 2010). However, over the last twenty years activities of added value with competitive advantage have been spreading more widely (Tulla, 2019).

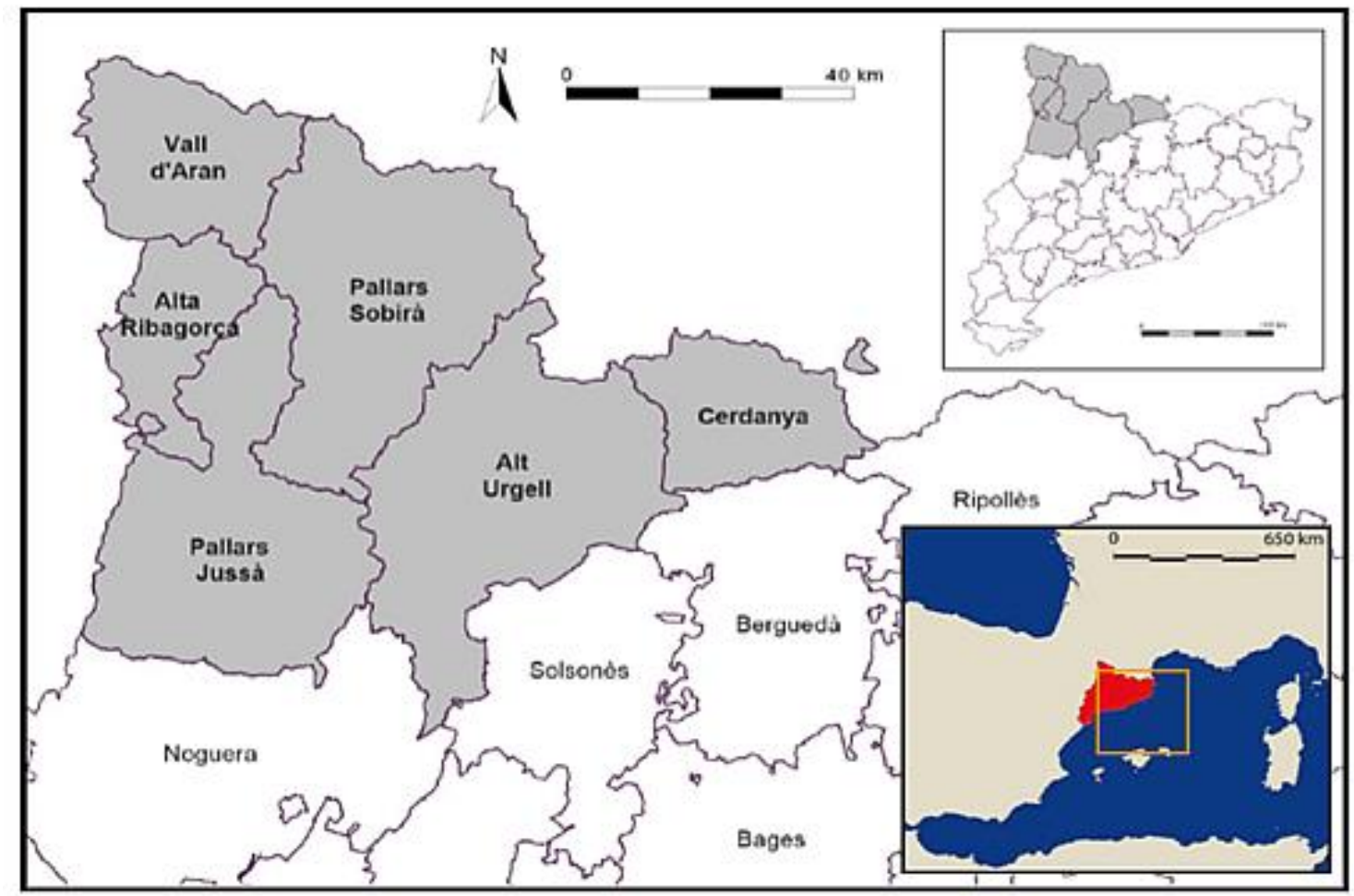

Fig 1. The High Pyrenees and Aran (HP\&A) region. Source: Adapted from ICGC.

At the end of the twentieth century, after decades of demographic and socioeconomic recession, a generalised recovery occurred in the region (Solé, 2012) and the tendency to depopulation slowed ${ }^{5}$. In socioeconomic terms, the most outstanding changes were expanded public and private services, a rise in purchasing power (Ventura, 2010), improved mobility and accessibility by land, and increasing demographic flows, especially with the arrival of foreign immigrants (Solé, 2012). As for public policy, a revaluing of the rural question mainly revolved around tourism, initially through rural tourism with support from governments through European Union rural development programmes and, presently, developing a variety of offers like hiking, thermal springs, active tourism, and so on (Tirado, 2017).

In a less tangible dimension, the revaluing of rural assets also appears with initiatives for recovering heritage and rural landscapes, largely fostered by rural development policies and directly influencing the collective imaginary and, accordingly, endowing these areas with greater interest and distinction (Solana, 2008). Finally, intensified environmental sensitivity (Atchoarena, 2004 ) is another decisive factor that heightens the appeal of Natural Protected Areas (NPA), not only as zones of conservation and places to visit but also as areas to live in and for engaging in economic activities compatible with conservation, as would be the case of projects connected with ICTs (Elbersen, 2005; Prados, 2009, Tulla, 2017).

5 The population of the HP\&A region of $5,775.5 \mathrm{~km}^{2}$ show the following evolution: 38,066 inhabitants (1717), 58,174 (1787), 107,627 (1860, historic maximum), 74,186 (1900), 75,582 (1950), 65,917 (1970). And 61,954 (1991), 61,067 (1996, lowest number), 64,067 (2001), 71,835 (2006), 77,189 (2011, maximum for $20^{\text {th }}$ and $21^{\text {st }}$ centuries), and $73,440(2015)$. 
The districts of La Cerdanya (Fig. 2) and Alt Urgell (Fig. 3) consist of wide valleys of countryside and fields with good soil that is easy to work, although they are surrounded by high mountains with villages built on the slopes.

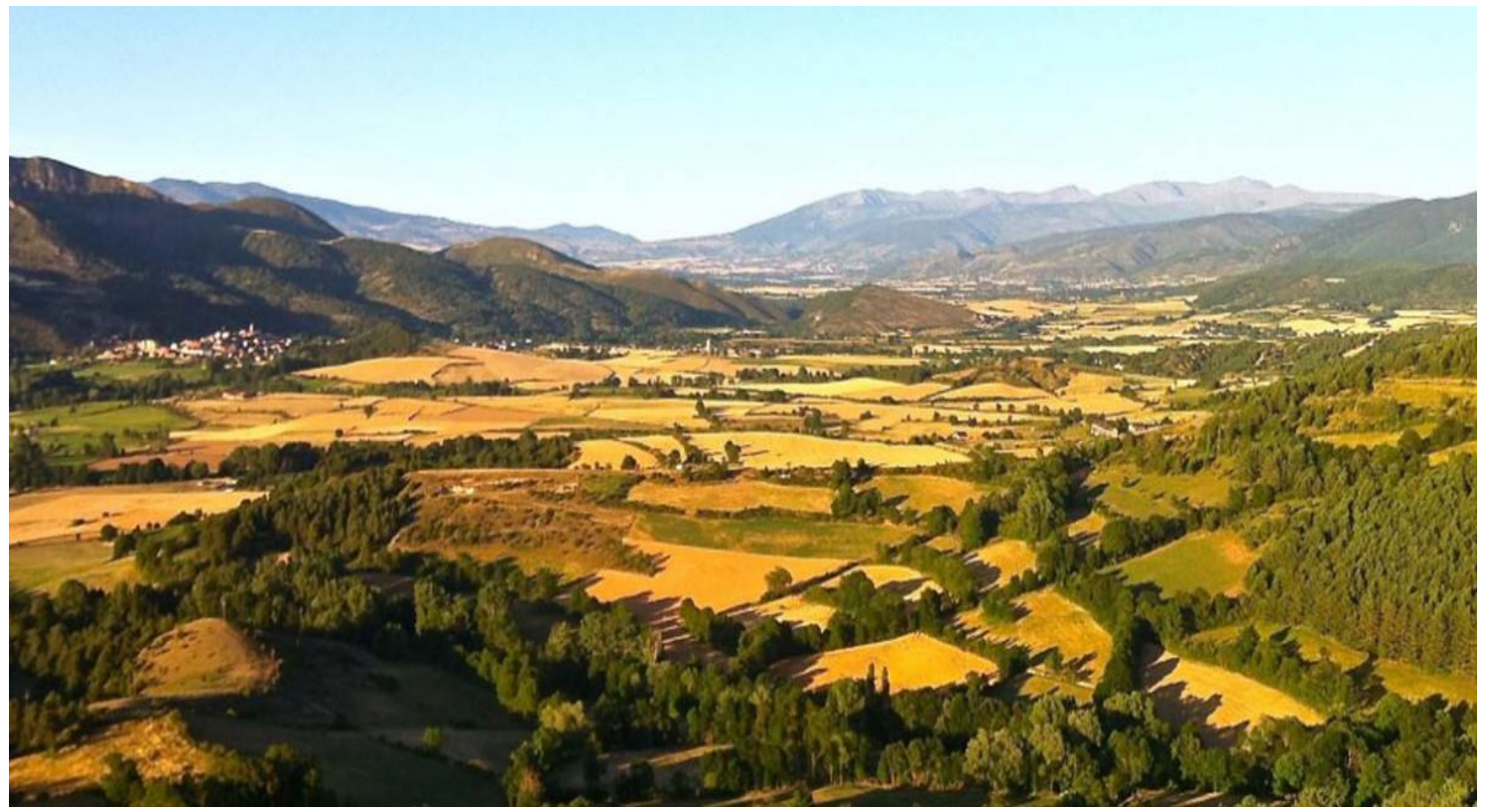

Fig 2. The La Cerdanya valley. Source: A. F. Tulla

In HP\&A, stockbreeding is improving productivity with the use of new technologies and innovative approaches (Mármol, 2016) but, at the same time, other companies also using ICTs and not dependent on proximity to high consumption areas and industrial zones are being established in locations near NPAs because of the quality of the scenery (Vera, 2003). In any case, the most relevant fact is that the region is increasingly being transformed into a smart rural area (Paneva, 2018).

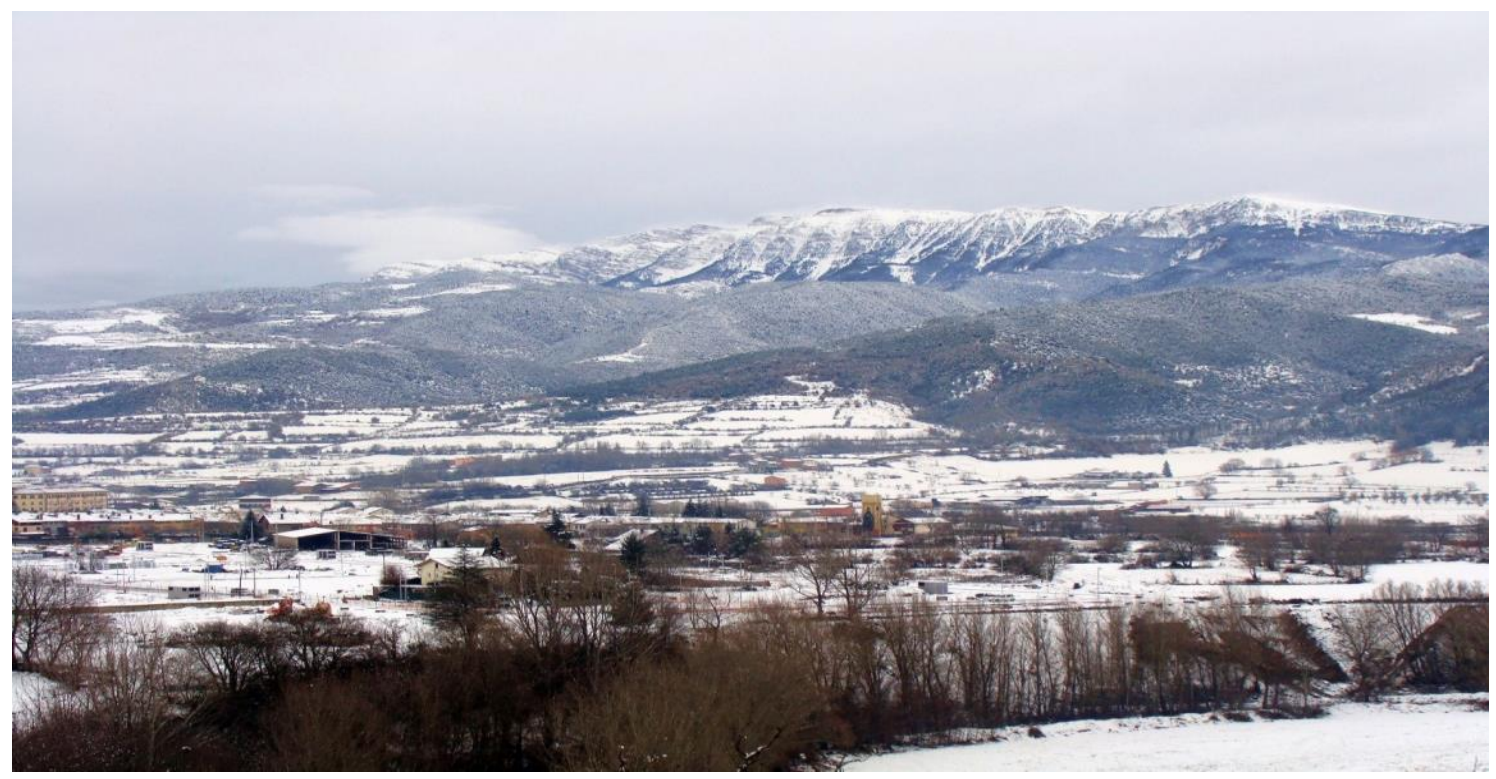

Fig 3. Fields in Urgellet in winter. Source: A. F. Tulla 


\section{Conceptual framework}

\subsection{Localisation factors of the new economy}

Neoclassical theories of industrial localisation show that criteria for deciding where to locate an enterprise are mainly based on raw materials (physical and natural elements) and the product. Outstanding among the main contributions by geographers is the work done by Hartshorne (1926), who identifies the fact that economic and social factors play a more important part than physical factors in localisation of an industrial activity. Subsequently, Renner (1947 and 1950), with his general principle of industrial localisation, suggests that localisation will be closer to abundant raw materials; closer to markets if the final product is fragile, voluminous, or subject to major fast changes of design and technology; closer to energy sources if power costs are very high; and, finally, closer to the job market when salaries of specialist workers are the most important overhead. Finally, Rawstron (1958) formulated the principles of industrial localisation (Three Principles of Industrial Location) aiming at maximum economic profitability in accordance with physical, technological, and business limitations.

Behavioural theories (Pred, 1967; Pred, 1969; Greenhut, 1956; Smith, 1966) incorporate extraeconomic variables in the process of industrial localisation when emphasising the conduct of the entrepreneur in decision-making. The businessperson is described as an irrational individual when wishing to maximise benefits and minimise production and transport costs.

Changes in the production system (Piore and Sabel 1984; Sabel 1989), worker specialisation, and the progressive technological (digital) revolution have resulted in modifications of business and locational structure culminating in a revamped trade structure. The vertical, hierarchical company is transformed into a horizontal, transversal business with a separation between central offices (management and design) and production and service areas, where the lines between highly dynamic strategies of distribution and exchanges become blurred. The technological revolution also affects companies as a result of the impact of e-commerce linking buyers and sellers online throughout the productive supply chain. All these changes in the production system and structure of the labour force entail changes in time, space, and costs (Vera, 2003).

The new economic structure introduces new agents and needs in business localisation. Skilled worker training centres, research institutions, universities, and public and private entities are agents which generate the synergies that enable developments in innovation, ICTs and knowledge creation. The main needs that define businesses are: proximity to other companies in the same sector, closeness to zones of $I+R+D$ and knowledge production, access to basic services, easy, rapid network access (fibre-optic broadband), infrastructure guaranteeing introduction of people and commodities-whatever their geographic location-into any part of the market, and public policies facilitating advances in innovation. Finally, a new factor is introduced, namely the wellbeing and quality of life of employees in companies working in I+R+D (Blanco, 2004).

To sum up, Christ (2009) has produced a typology of causes of agglomeration of productive activities, classifying them under two headings: first-nature causes, referring to exogenous determinants of localisation, for example, physical and natural aspects, and second-nature causes like endogenous elements of the agglomeration (Figure 4). 


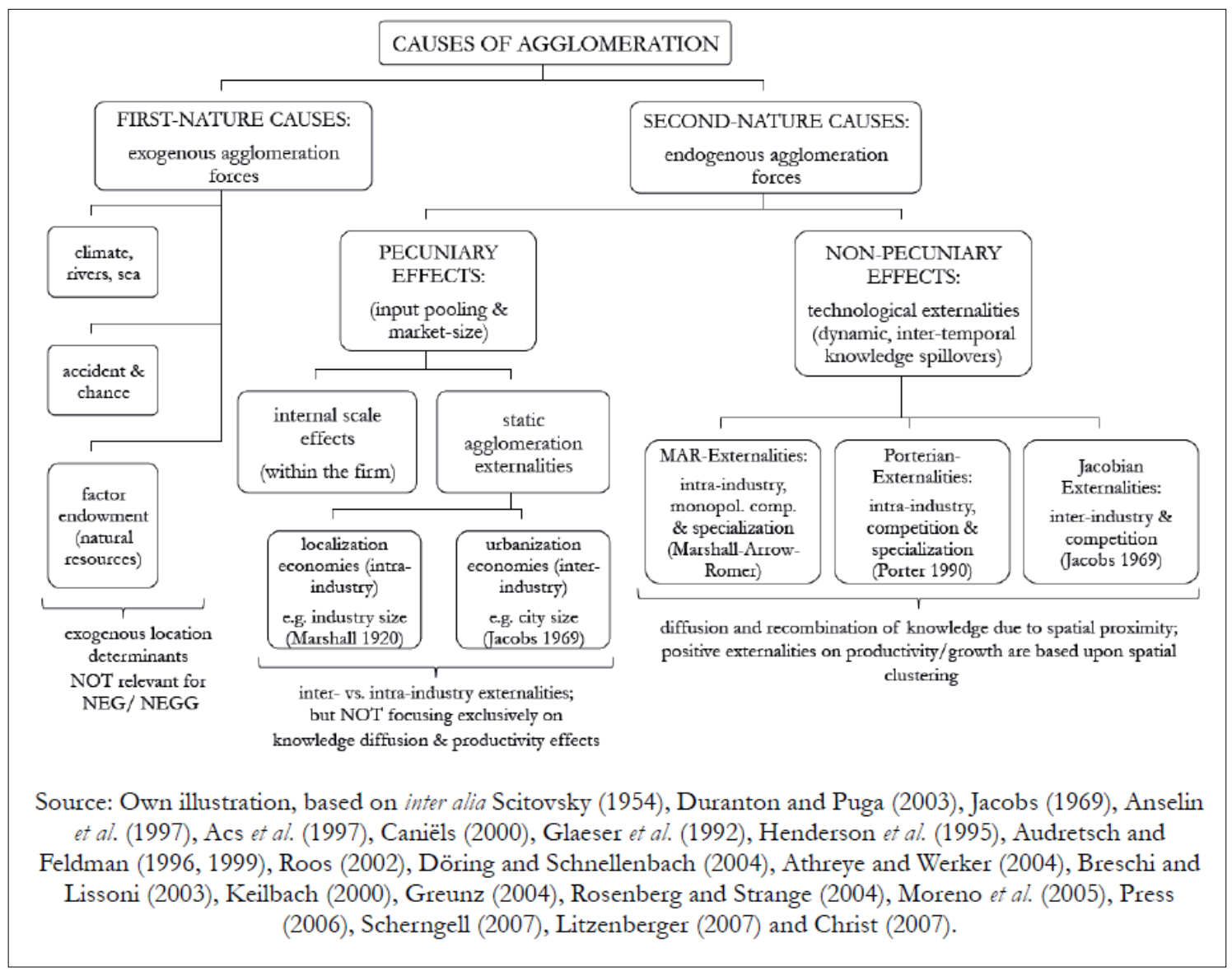

Fig 4. Main localisation factors. Source: Christ, 2009

There are also other references (Barners, 2003; Pallarès-Barberà, 2003), notable amongst which are technological externalities, worker training, cooperation and competition among business networks, and specialisation. These localisation factors are more common in urban agglomerations favouring the creation of competitive clusters and $I+R+D$ advances. However, there are cases of companies which, contrary to what the literature assumes, are located in remote zones like in Scotland ${ }^{6}$ where digital tools facilitate SMEs expansion (Loo et al., 2015). Where new elements related with the importance of spatial loyalty are introduced, these theories are examined in a framework of firm territorial embeddedness (Granovetter, 1985; Pallarès-Barberà, 2004), defined on the basis of the incorporation of small and medium-sized businesses in a particular area and taking into account the social and cultural aspects of the company's location. Besides that, ICTs offer the possibility of distribution to companies of high added value in remote zones, throughout the territory.

\subsection{Innovation and ICTs}

Interest in innovation and communication technologies has been growing since the end of the twentieth century. ICTs can be analysed from the standpoint of industry with a focus on studying the effects brought about by a company's innovation in productivity, internationalisation (Laursen and Salter, 2006), competitiveness (Hidalgo et al., 2008), cost reduction, and customer satisfaction (Ifinedo, 2011). From this perspective, it is possible to identify the determinant factors and strategies of internal organisation of a company's performance, for example in diversification or the efficiency of innovative activities it is engaged in. Other indicators are innovative behaviour in the geographic spaces and environments where companies are located, highlighting spillovers (Levin and Reiss, 1988), the social capital accumulated in the territory (Landry et al., 2002; Lundvall, 1992), and other factors directly affecting the orientation, intensity, and performance of innovative endeavours. Joint analysis of

\footnotetext{
${ }^{6}$ RCUK dot.rural Digital Economy Hub, University of Aberdeen
} 
the three perspectives constituted by industry, business, and territory is necessary in order to explain how they interact together and to identify which of the three elements is most influential with regard to the innovative behaviour of companies (Nieto-Antolin, et al. 2011).

The OECD presents two approximations to innovation. First is the Frascati Manual (2002), which defines technological innovation as the transformation of an idea in a new or enhance products being introduced into the market, or a new or improved process in both industry and trade. Second, the Oslo Manual (2005), distinguishing between the technological innovations in the product and in the process, sees product innovation as being based on the creation of new products or services, and in improvement in characteristics, presentation, and quality of alreadyexisting products. Process innovation entails the introduction of new production processes or modification of existing processes with the aim of cutting costs. Innovations might have repercussions for the characteristics of products which sometimes require new machinery and equipment. These changes do not affect all the processes and factors involved-among them the workforce-in the same way or at the same speed (Hidalgo et al., 2008).

ICT technologies have contributed to Business to Business - B2B communication by synchronising suppliers and clients in different countries. Similarly, e-commerce has favoured access for clients in remote areas by reducing contact costs (Mayer et al. 2013). The introduction of new technologies has not occurred homogeneously in all companies, thus giving rise to disparities between those that use them and those that do not. Accordingly, the administration is designing policies with a view to minimising the digital differences among companies and also regions (Addison and Heshmati, 2003). Companies that are able to rise to the challenge of innovation, wherever they may be located, will then be equipped to compete in local, national, and international markets.

The innovation in the productive processes has meant an improvement of the efficiency and productivity as well as the internalization of the companies. ICTs have helped this change that has also frequently involved an internal reorganization of the companies (Larson and Salter, 2006; Cheng and Lin, 2012).

\subsection{Sustainable rural development (SRD)}

The concept of rural development (RD) might be viewed as having a dual focus: integration and transversality. RD works with all dimensions of the rural world (economic specialisation, cultural heritage, social and human capital, environment, et cetera). However, it is simultaneously based on the social and economic wellbeing of the population, which is measured more by quality of life in the countryside than by GDP per capita in the area. Rural areas are increasingly commercialised (Best, 1989), which then requires the existence of public policies in order to limit negative effects (Perkins, 2006). Nevertheless, in an attempt to reduce urban dependence on the rural fact as a "commodity", a modern, rational, and technologically advanced society, with new activities, is now being developed (Taylor, 1989).According to FAO/UNESCO (Atchoarena, 2004), from both social and environmental perspectives, RD seeks to bring about equitable and sustainable improvement in living conditions of the rural population by means of better access to goods (natural, physical, human, technological, and social capital) and services, and also control of productive capital, all of which makes it possible to improve subsistence sustainably and equitably.

SRD must combine economic, social, and environmental policies, when "Sustainable Development" is a concept formulated in the Brundtland Report (1987) according to which development to satisfy present-day needs of the population should not jeopardise resources that might be necessary for future generations

One of the core characteristics of the SRD concerns, besides multifunctionality (Wilson, 2007), is the form of rural development known as "eco-economy". Firstly, this aims to avoid damaging the environment by excluding industrial pollution, chemical agriculture, or simply breaking up the territory with an excess of infrastructure leaving many abandoned and unusable spaces (Kitchen, 2009). Secondly, added value is sought in rural activities with high-quality, increasingly accessible landscape, and in NPAs (Ray, 1999). Finally, value is given to human capital with 
endogenous development (Flora, 2008) together with formal and informal social networks, while benefitting from ICTs, which produce social capital in RD (Anderson, 2003).

Since the 1960s, RD has tried to find solutions for at least three problems: (1) finding a viable economic base for rural areas; (2) achieving an adequate level of quality of life and good environmental conditions for their population; and (3) reorganising the local rural society in a globalised world but without sacrificing its identity. Then, resilience appears as a process of social dynamics, determined by the ability of communities to act collectively and work together to resolve shared problems (Ploeg, 2000).

The concept of "resilience" incorporated into the social sciences less than twenty years ago, can also be used in the field of RD linked to ICTs (Roberts et al., 2017). The idea of resilience refers to the capacity of a social-ecological system to absorb disturbances and reorganise when being subjected to forces bringing about change and, at the same time, remaining capable of conserving the basic elements of functions, structure, identity, and feedback in the system (Kock Exterckoter, 2016).

Looking to policies coming from the administration, we shall comment on two areas. First, since 1989, EU Common Agricultural Policy structural funding has been given to rural regions with three main objectives: (1) to compensate for territorial imbalance by providing better access to economic and social opportunities; (2) to correct socioeconomic inequalities, especially between genders and young people; and (3) environmental protection and implementation of policies favouring sustainability. Second, this means in practice "introducing new SRD policies" like the new methodology of the LEADER Programme (Esparcia, 2000), which focuses on spatial design of rural polices instead of adopting a sectorial focus and decision making in economic policies from bottom to top rather than top to bottom, among other features.

SRD involves giving priority to the use of local resources with processes promoting creation of products with added value by making the most of the comparative advantage of mountainous rural areas (Tulla, 2019).

\subsection{ICTs in the local development: smart rural areas}

"Smart and Competitive Rural Areas" is one of the broad themes of the European Network for Rural Development in the 2014-2020 programming period (ENRD Publications, 2018). The initial focus was studying how certain services (health, social services, education, transport, trade, and energy use, among others) could be improved and be made more sustainable using ICT tools as well as actions and projects led by local communities. In a second stage, some projects using innovative ways for creating more sustainable rural areas with support from the Rural Development Programmes (2018) have been selected to receive European funding through EU Action for Smart Villages (2018). There is a systematic literature review on ICT availability in rural areas published in a special issue of the Journal of Rural Studies (Salemink et al., 2017).

Digital technologies are an innovative instrument that can improve services as well as industrial production in the field. This will improve the opportunities of the smart villages and their territorial environment to access the SRD (Hess, 2018; Paneva et al., 2018).

In our research we have aimed to garner the lessons of projects "for digitising rural areas" presently being carried out in Germany ${ }^{7}$, France ${ }^{8}$, Cornwell $(U K)^{9}$, Spain ${ }^{10}$ and Finland. ${ }^{11}$ Smart villages share several characteristics: (1) seeking people to take initiatives in order to find practical solutions that will make it possible to transform the locality while also keeping a balance between efficiency and equity; (2) using digital technologies only when necessary and not just because they are fashionable, in order to serve society better; (3) more than local,

\footnotetext{
7 https://enrd.ec.europa.eu/sites/enrd/files/enrd_publications/digital-strategies_case-study_de.pdf

${ }^{8} \mathrm{https} / / /$ enrd.ec.europa.eu/sites/enrd/files/enrd_publications/digital-strategies_case-study_fr.pdf

${ }^{9}$ https://enrd.ec.europa.eu/sites/enrd/files/enrd_publications/digital-strategies_case-study_uk_0.pdf

$10 \mathrm{https}: / /$ enrd.ec.europa.eu/sites/enrd/files/enrd_publications/digital-strategies_case-study_es.pdf

11 https://enrd.ec.europa.eu/sites/enrd/files/enrd_publications/digital-strategies_case-study_fi.pdf
} 
having a regional perspective and including digitalisation of agricultural activities in the surrounding countryside; (4) establishing new ways of working together for farmers and other agents of rural municipalities, especially civil society and private companies; and (5) thinking more about each case in order to diagnose the situation and make appropriate suggestions instead of looking for a standard model that could be applied to any case (Hess, 2018).

Interestingly, the work group "ENRD" has presented an implementation plan titled "A Digital Ecosystem for a Smart Village" (Hess, 2018) in which four layers of analysis are discussed: Society, Digital Services, Technical Platform, and Digital Infrastructure. The plan is organised as a digital ecosystem with four elements: "Smart village living lab, Partner \& network (digital hubs), Business model, and Digitisation roadmap".

At the "society" level, the aim is to involve different stakeholder groups needed for implementing the digital innovation projects in rural areas. This entails working with local administration, the private sector, and local residents if the initiative is to be successful. Recommendations include: (1) developing initiatives of ICT support systems in local service centres; (2) reinforcing digital education through groups of volunteers in order to avoid digital illiteracy; (3) training agents to encourage digital techniques in support of projects; (4) promoting mutual support among local residents to strengthen the digital platform; (5) consolidating the smart village through schools and multifunctional tasks of the actors involved; and (6) developing digital capital among productive initiatives and services in the rural environment (Hess, 2018).

The "digital services" layer aims to promote services and simple applications that will make it possible to expedite the functioning of rural ecosystems. This means streamlining the work involved in the local offer of basic products and factors of production in online platforms that supplement direct contact. This can be improved by promoting communication and transparency, as well as adopting solutions for sustainable mobility. Health services, and therapy for groups at risk of social exclusion (Tulla, 2018) can also be improved by using online platforms. In any case, it is necessary to reinforce online education and training by means of these platforms.

The "technical platform" layer takes the approach that services can be qualitatively improved when online platforms are used in the smart village. This is a technically innovative process but its form is also such that it can reach every corner of rural areas. In the initial phase, a public or Third Sector subsidy will probably be necessary since there are few users, few transactions, little experience, and scant ability to operate in a complex digital ecosystem. In this regard, the "digital infrastructure" layer is very important since it adapts to the needs of rural territories which need broadband access" 12 so that they can fully implement ICTs, the key element for digital transformation of rural areas. It is also possible that sensors for making applications available in isolated farms, smart energy, and other technologies based on the Internet will be necessary.

A fifth layer, the "organisational ecosystem" is basic for innovative digital projects since it requires an amount of work to be carried out in each sphere of the rural territory. This must include instruments like a living lab, which allows for joint work among researchers. Examples of this are the Cadi Cooperative in our study area, initiators of a range of projects, a digital hub facilitating guidelines for each type of service or production, and a "digitisation roadmap for rural services", making it possible to work with an overview of digital innovation in all the activities of this territory (Hess, 2018).

Finally, it is necessary to draw attention to social innovation for revitalising social services. In this regard, the example of the province of Bolzano-Bozen (north-eastern Italy) is instructive. Between 2007 and 2014, a series of projects were implemented in which a group of women offered to look after hundred children or take care of elderly people (in 32 farms) in order to help with the integration of agrarian resources into environmental concerns and teaching practice ${ }^{13}$.

\footnotetext{
12 https://enrd.ec.europa.eu/sites/enrd/files/tg1_rural-businesses_brief_digitisation.pdf

13 https://www.kinderbetreuung.it
} 
Similar endeavours may be found in Catalonia where social farming along these lines has also been carried out (Tulla, 2018).

\section{Methodology and techniques}

We have carried out a review of the literature and searched for links related with ICTs, smart rural areas, sustainable local development, and localisation theories. One major contribution has been in-depth interviews, mostly online, with three experts (one for each topic explained in the results) and twelve supporters of digital experiences in rural areas. Three interviews were conducted with companies, 5 in the agricultural sector and 4 in relation to digital services. The main questions refer to the nature of digital innovations, their diffusion process and the level of acceptance by different actors.

Moreover, we have carried out follow-up work with some of the cases we have studied: Kappa and Grifone textiles for sports clothing (Grifone, 2018); Ogilvy (2018) in the sector of productive services; and, in the livestock sector, the Cooperativa Cadí (Gascón, 2015) and the Catalan women livestock association (Dones i Món Rural, 2018; Dones ramaderes a Catalunya, 2018), following the example of women farmers in Spain (Ganaderas en red, 2017). Their aims are various but all give priority to preserve the natural and agrarian environment and have introduced digital social networks as their basic instrument of communication and cohesion among the member entities.

The topics in the interviews with industrial and service enterprises, complemented with online research, are basically matters concerned with company organisation (product design, production phases, marketing and distribution, and the use of ICTs in transversal analysis), human resources, funding, and localisation criteria. By contrast, the interviews with representatives from cattle farms and dairy products businesses, the subjects covered have mainly focused on diffusion of digital techniques. First, they have concentrated on organisation of activities (inputs and products monitoring, accounting, individualised knowledge of animals, etc.) and, second, there is a development of online social networks between producers and suppliers, customers and processing companies, and also among men and women farmers in order to exchange experiences and join forces. The third and final step is computerisation of farm work using robots. In this case, food security has also been improved with the use of digital technologies.

Interviews with experts and online searches have been concerned more with services related with the territory as a whole and defining this region as a smart rural area. In this regard, it has been possible to confirm how the greater part of personal services (restaurants, hairdressing salons, businesses) use ICTs, since in this extensive area with a low population density, they enable better interconnection among the inhabitants. ICTs are also used to this effect by productive services like input provider companies, financial services, and administrative agencies, among others. Nevertheless, ICTs are mostly incorporated in the tourist and cultural logistics and services. The "transport on demand" service, operative in the Alt Urgell district with support from the Regional Council" ${ }^{14}$ since 1991 (Gurrera, 1988), is a supramunicipal entity that was subsequently adopted in other rural areas. Analysis of this service and its approach, and of others using ICTs, for example telephony, health, and cultural events has been carried out in the framework of the Mab-6 (High Pyrenees) programme of UNESCO (Ganyet, 1993).

\section{Results: Information and Communication Technology in the case studies}

Since the early years of the twenty-first century, Catalan businesses have increased their use of ICTs in infrastructure (most notably with Internet connection and mobile phones), organisation, company management, design, and worker training, as well as in e-commerce and after sales service. The new business organisation resulting from intensive use of digital technologies is

\footnotetext{
14 "Consell Comarcal" means District Council, an administrative body which manages services for all the municipalities of the territory covered by the district. Its jurisdiction is based on Law 6/1987 of 4 April concerning the regional organisation of Catalonia, and the Legislative Decree 4/2003, of 4 November, of the revised text of the Law on regional organisation of Catalonia.
} 
structured around integration of the company's internal processes, management of information, customer management, planning and resources management, and supply management.

The National Statistics Institute (INE 2016a and 2016b) with a Survey on the Use of Information and Communications Technology (ICT) and another on e-Commerce in Companies in 2016 together with a report published by the Government of Catalonia (2017)," Innovation Barometer in Catalonia, 2014-2017", which complement each other to explain the evolution of ICTs in businesses in Catalonia.

Tab 1. Technological and non-technological innovation in Catalonia 2012-2016. Source: INE (2017)

\begin{tabular}{|c|c|c|c|c|}
\hline \multirow{2}{*}{$\begin{array}{l}\text { TECHNOLOGICAL AND NON-TECHNOLOGICAL } \\
\text { INNOVATION }\end{array}$} & \multicolumn{2}{|c|}{ Value } & \multicolumn{2}{|c|}{$\begin{array}{c}(\%) \text { of total of } \\
\text { businesses }\end{array}$} \\
\hline & 2012 & 2016 & 2012 & 2016 \\
\hline Innovative businesses & 8,952 & 9,282 & 29.3 & 32.9 \\
\hline Businesses with technological innovation & 4,415 & 4,024 & 14.4 & 14.3 \\
\hline Businesses with non-technological innovation & 7,318 & 7,933 & 23.9 & 28.1 \\
\hline
\end{tabular}

The first results obtained indicate that, since 2012 , there has been a rise of $2 \%$ in the volume of companies introducing innovation, among which $14 \%$ refers to productive innovation as in the Oslo Manual (2005). Moreover, higher percentages, 23.9\% for 2012 and $28.1 \%$ for 2016 , signal changes in organisational methods and, in particular, implementation of new marketing strategies (Table 1).

In terms of number of workers, it may be observed that in 2016, the districts of HP\&A have the highest business density of Catalonia (average of 41 firms for 1.000 inhabitant), and those companies have mainly less than 10 employees (Government of Catalonia, 2017). Catalan companies have reached the first phase of digital change consisting of having Internet connection and presence. It is important to remark that in the case of micro-enterprises and companies with fewer than ten workers, web pages and e-commerce are indicators of increasing use of ICTs in commercial publicity and business promotion and transactions (Table 2).

Tab 2. Online services in companies according to number of workers, Catalonia 2007 to 2016. Source: INE (2016), IDESCAT (2016)

\begin{tabular}{|c|c|c|c|c|c|c|}
\hline & \multicolumn{3}{|c|}{$\begin{array}{c}\text { Companies with } 10 \text { or more } \\
\text { workers }\end{array}$} & \multicolumn{3}{|c|}{$\begin{array}{c}\text { Companies with fewer than } 10 \\
\text { workers }\end{array}$} \\
\hline & 2007 & 2012 & 2016 & 2007 & 2012 & 2016 \\
\hline Computer & 98.1 & 98.5 & 99.7 & 67.6 & 77.1 & 88.2 \\
\hline Internet connection & 96.3 & 97.1 & 99.4 & 56.9 & 70.2 & 80.8 \\
\hline Using social media & & & 54.7 & & & 29.2 \\
\hline $\begin{array}{l}\text { Purchase of cloud } \\
\text { computing services }\end{array}$ & .. & .. & 31.5 & & & 12.7 \\
\hline Web page & 63.2 & 74 & 83.8 & 14 & 22.3 & 28.1 \\
\hline Email & 95.9 & 96.9 & ... & 52.1 & 66.9 & .. \\
\hline Intranet & 23.0 & 75.5 &.. & 2.6 & & \\
\hline Buying by e-commerce & 25.2 & 25.4 & 36.5 & & & 15.4 \\
\hline Selling by e-commerce & 14.0 & 16.6 & 25.1 &.. & & 4.3 \\
\hline
\end{tabular}

In these companies, e-commerce has been growing since 2003, especially with regard to purchases, with a figure of $15.4 \%$ in 2016 . More widespread use of web pages and Internet promotion has brought about a rise in sales. The main market is in Catalonia, followed by Spain. 
Incorporation of ICTs in companies by territorial areas is directly related with the possibility of Internet connection. The lowest figure for Internet access in homes and businesses is $84 \%$ in the HP\&A (2016) when the average for Catalonia is $85.7 \%$. Among the seven districts comprising HP\&A, it is in Seu d'Urgell where $95 \%$ of the municipalities have broadband and Internet access (IDESCAT, 2017).

\subsection{New technologies and innovation in small and medium-sized companies (SME)}

The SME in the area under study represent a range of economic sectors. Among companies producing mountain clothing there are two cases with different results. The first, Kappa Sports, a foreign owned company, had a branch in the area from 1997 until 2003 but, in spite of enjoying some initial advantages (access to ICTs, workforce, privileged localisation), it relocated to a more strategic centre. The other company, Grifone S.A., a locally owned enterprise, was able to deal with changes in business structure and respond appropriately and could therefore remain in the territory, as we shall describe below. The difference between the two companies shows the resilience of companies of local origin by comparison with the uprooted nature of foreign companies.

Founded in Terrassa in 1980, the Grifone S.A. brand was acquired in 1984 by a group of 38 entrepreneurs from Alt Urgell who, aiming to offer jobs, founded the company GRIFONETèxtil SEU S.A. ${ }^{15}$ with headquarters in Seu d'Urgell. The company's evolution is directly connected with cooperation with other companies like Natura i Tecnologia Indústries d'Andorra (Naturtec Industries) in 2007, which increased its capital and expanded some of its online publicity and promotion. The enterprise Landher Montana, ${ }^{16}$ founded in 1991 in Gasteiz in the Basque Country, specialises in e-commerce sales and also sells to the company, which makes technical sports clothing (mountaineering, skiing, cycling, et cetera) and professional equipment with the aim of showing mountains from another perspective. The main clients are amateur and professional sportspeople and members of the security forces (local and regional police), foresters and employees of large enterprises. The distribution of these products is done through specialist retail outlets in Catalonia, Spain, and Andorra. The company has ecommerce distributors in Europe (France, Austria, Norway, Finland, UK, Germany, and Italy) and also in Asia (Korea, Taiwan, Hong Kong, and China).

At present, it has 30 employees, half of them women, working in design, logistics, and product sales, apart from liaising with other countries where the productive phase is carried out. The design and company management area connects with institutions and research centres located in the Metropolitan Area of Barcelona, thanks to ICTs, which are used not only in designing fabrics and items of clothing but also for logistics, internal organisation, and storage as well as sales and, in particular, after sales service for analysing the needs of users of mountain sports clothing. Through its web page it offers meetings for customers, information about mountain matters (mountaineering), training grants related with mountains, and a consultation service regarding questions concerned with technological advances in textile design. This company sponsors sports activities that foster social relations and activities in Alt Urgell.

Innovation and working together with research institutes and universities are very important for the company's progress. Notable, firstly, amongst these joint projects are relationships with the business school ESADE and the Polytechnic University of Catalonia (UPC) with the aim of obtaining better knowledge of the needs of customers and being able to offer more competitive goods that are better tailored to their requirements. Secondly, partnership agreements with enterprises specialising in business and new technologies enable better management in the supply chain, thus maximising the company's efficiency. Thirdly, in this phase of innovation with fabrics used in designs for making ergonomic sports clothing, customers need to work with technicians who are specialists in product design. The problem here is an unskilled workforce that does not have access to a network of institutions or university centres.

\footnotetext{
${ }^{15} \mathrm{http}: / /$ www.grifone.eu

16 http://www.landher.net/
} 
Owing to its use of ICT and improvements in business management, the Ministry of Innovation, Universities, and Business of the Government of Catalonia awarded its 2007 Competitiveness Prize to GRIFONE - Textil la Seu S.A. in recognition of the degree of innovation achieved in its products, especially its introduction of a system for creating and developing new specialised products. The company's I+R+D investment has meant an annual growth of $20 \%$ in which one outstanding result is having consolidated improvements in both technological alliances with suppliers of fabrics and with distributors of the products.

The owners' feeling of identity with the zone is the main reason why the company is located in the Pyrenees, which is normally seen as a region that is not very suitable for establishing $I+R+D$ companies. However, ICTs, the Internet, and e-commerce have all brought these faraway places closer (Pallarès-Barberà, et al.; 2004).

Another case of an innovative company located in the area under study is the Ogilvy \& Mather agency which, founded in New York (1964), is a marketing company specialising in public relations. In 1989, it opened an office in Barcelona with the aim of moving into new markets and establishing start-ups. The company has been opening offices in several towns and, in 2018; the Seu d'Urgell council suggested that it could open a new branch there with the aim of working on mobile telephony software. Connection is required but, once this is established, being located in a remote area is possible. The result has been beneficial, not only for Ogilvy \& Mather but also for the area as a whole, with new jobs on offer as well as employment for some thirty engineers. Skilled workers have stayed in the area or have returned, and living standards are better because the pay is higher and costs are lower than in the city of Barcelona.

\subsection{Expanding use of ICTs in agrarian activities}

In 2012, La Cerdanya district, including municipalities on both French and Spanish sides of the border, were home to 90 cattle farms, producing 70 million litres of milk (Pallarès-Blanch, 2013). By 2017, the number of these farms had dropped to 78 (Figure 5), although production had risen to 75 million litres, of which $90 \%$ is processed in the Cooperativa Cadí (Gascón, 2015).

According to Toni Torrent, a Cadí vet and president of the PDO ${ }^{17}$ association for HP\&A butter and cheeses, ten farms are using robots and another five are currently installing them (Figure 5). This kind of installation involves major changes in farm functioning since the robots, computerised and technically very sophisticated, milk the cows by themselves. Doing so, they immediately send all the data to a computer, and even the farmer's mobile phone. This information is very complete since it indicates which cows have been milked, and how many remain to be milked, the time, the production, if the animal is in good health, or if it is ailing (with mastitis, for example), or if it is on heat, and so on. This kind of enterprise is very attractive for young people and it has been shown that many of them are now making a living from, or returning to the livestock farming. Moreover, the Cooperativa Cadí is also functioning as a kind of coaching institution, training new generations in the use of these innovative technologies.

It is also important to highlight the fact that women livestock farmers (Dones ramaderes a Catalunya, 2018) have established an association with a range of professional and social goals, among them creating an Instagram account for exchanging technical knowledge and comments on farming matters as well as social events, and social views. Notable among the latter is the opinion that the wellbeing of the animals is essential in livestock breeding (Figure 6), in opposition to the idea of factory farming in many livestock enterprises. Some of these women farmers are located in the HP\&A zone.

\footnotetext{
17 Protected Designation of Origin, recognised by the European Union.
} 


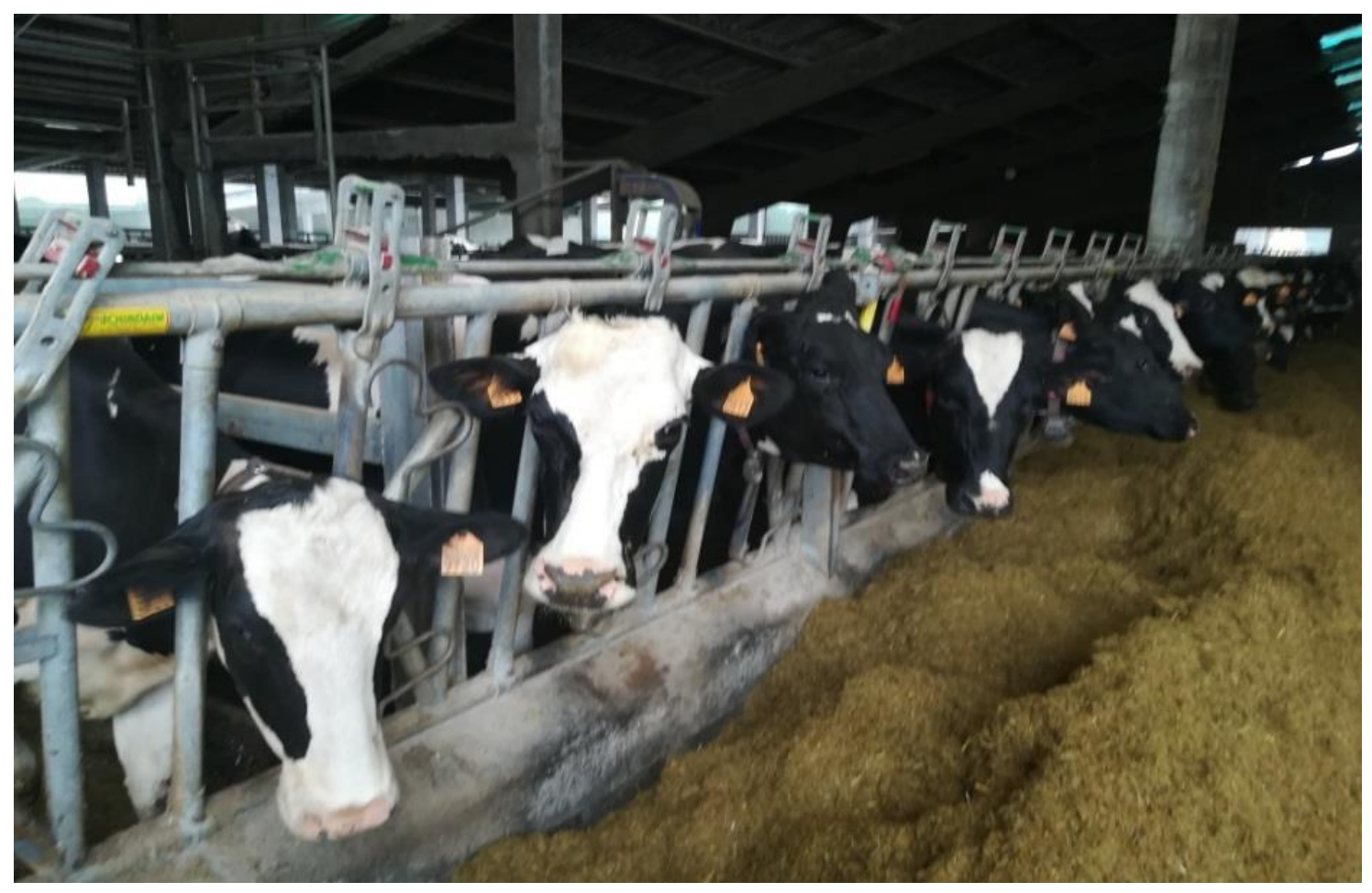

Fig 5. Dairy farming. Source: A. F. Tulla

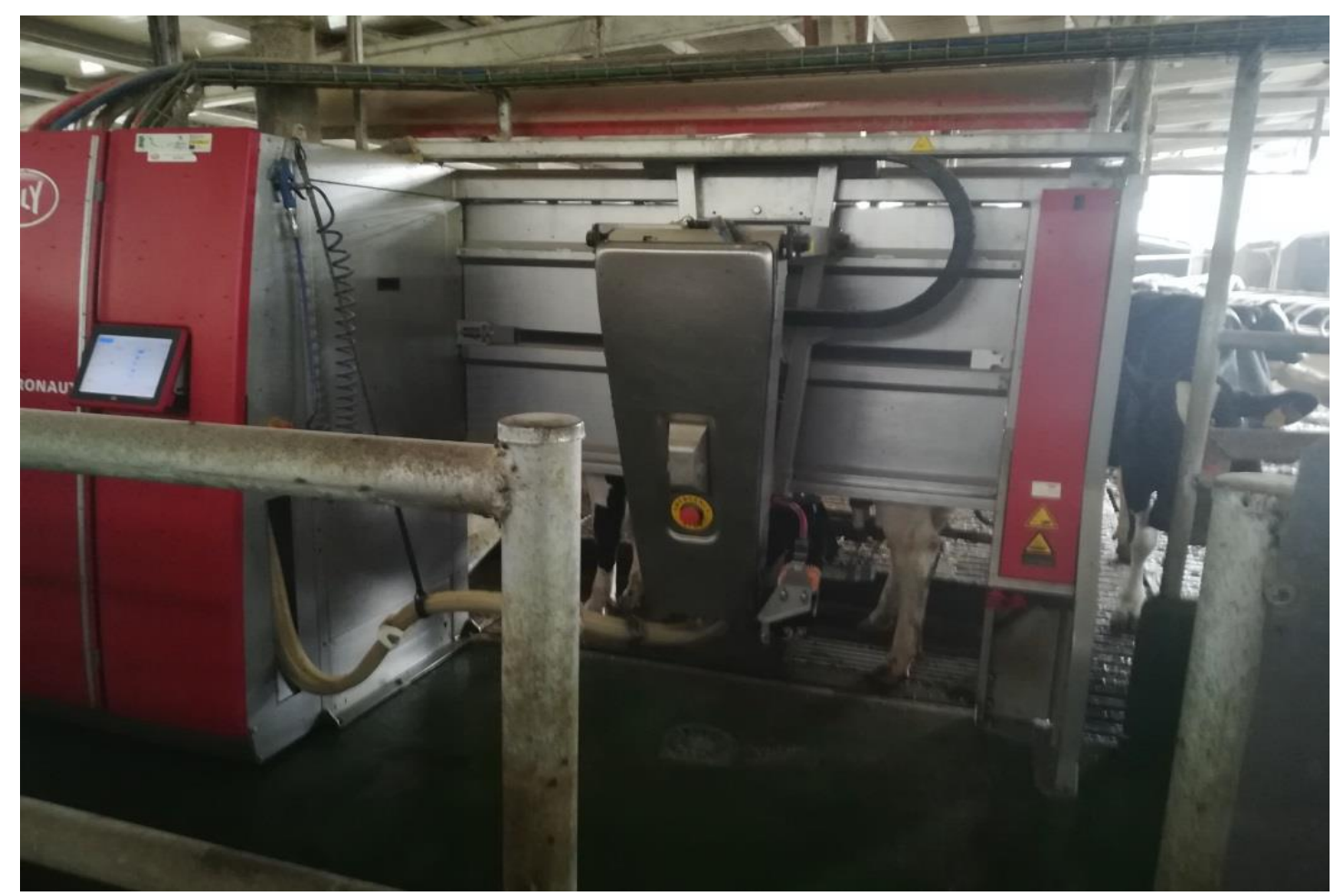

Fig 6. A robot milking a cow. Source: A. F. Tulla 


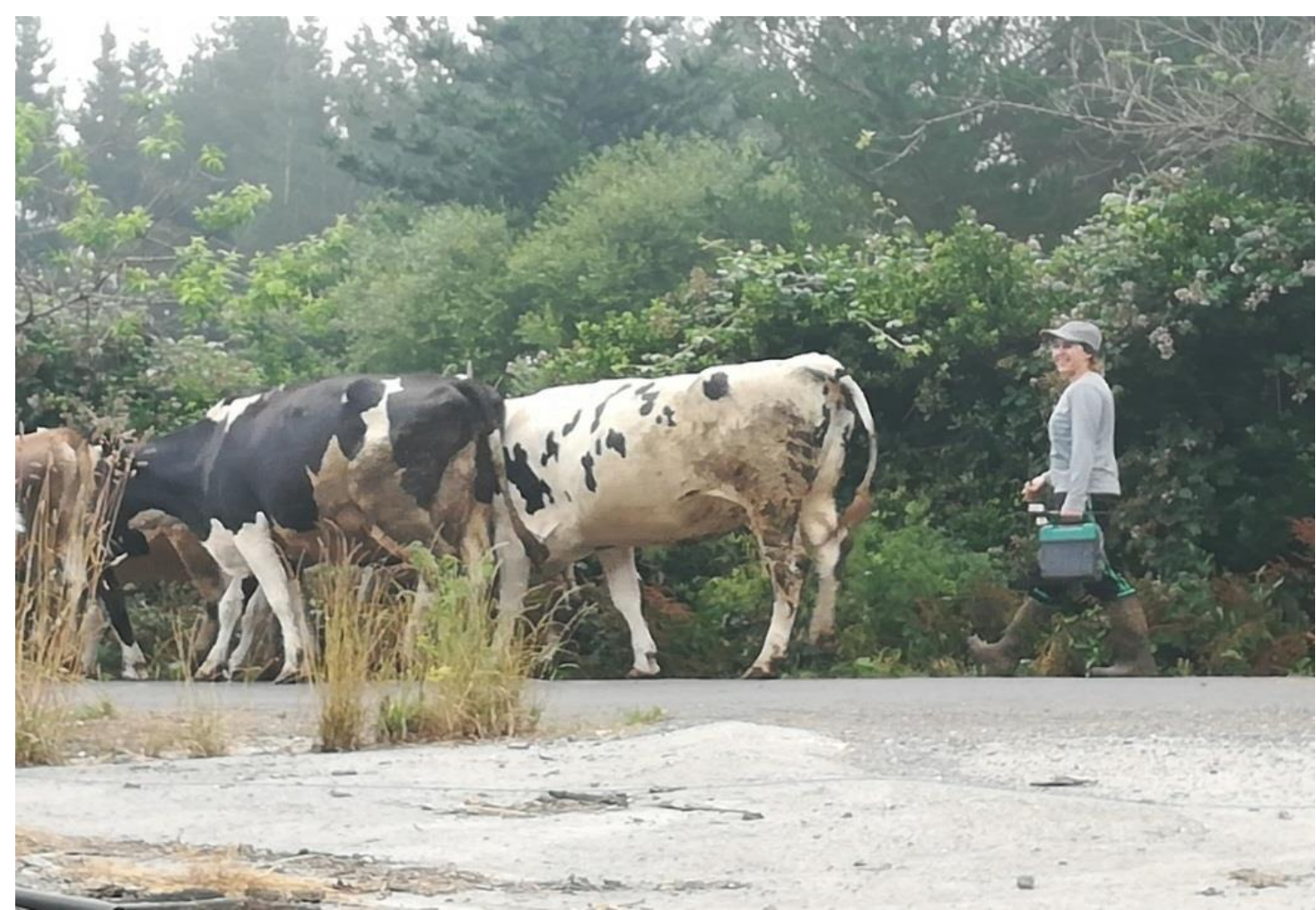

Fig 7. A woman livestock farmer taking cows to the fields. Source: A. F. Tulla

The predominant profile is that of women who, aged between thirty and fifty, live with a partner and children. They have studied or worked in urban areas but, as a result of the economic crisis or because of a desire to improve their living conditions, have moved to the country (Solé, 2012), working in properties connected with the family, renting, or buying them. A small proportion has dairy cows, although the majority has sheep, goats, poultry and ducks (PallarèsBlanch, 2015). They tend to focus on artisan products, although this requires considerable investment in installations to comply with the stringent standards of Catalonia's agri-food regulations. In general, it can be stated that their use of ICTs is mainly in online social networks and, more selectively, concerned with mechanisation and computerisation of agri-food processing installations.

\subsection{Tendency towards a smart rural territory.}

Most mayors from the larger towns of HP\&A have been hoping to attract initiatives of professionals and businesspeople that are using ICTs with the aim of locating in the region endeavours that do not depend on economies of agglomeration as it happens in urban areas (Ganyet, 1993). Hence, several studies and strategic plans are now underway in order to obtain improved computerised results in transport services and logistics so as to create a territorial environment that favours new entrepreneurs (Mateu, 1988). In the beginning, it was a struggle to get telephone landlines provided in all villages and farmhouses so that they could use the Internet. Next, there was a need to rectify the fact that the cable networks have overlooked rural areas with a low population density and, consequently, to develop digital platforms offering a wide range of services. Initiatives at the local level are also appearing.

In 2003, the Centre for Telecommunications and Information Technologies (CTTI) of the Government of Catalonia launched a public tender for the procurement of a telecommunications (Tcs) network operating in such a way as to cover all the municipalities in the country and, in particular, in rural areas where the big Tcs companies had shown no interest in investing (Grau, 2006). However, owing to the onset of the economic crisis in 2008 and lack of interest in investing in remote areas with small populations, the project was only partially implemented. Then another project, RuralNet (2003), was encouraged to provide cover for the 77 municipalities of HP\&A with fibre-optic infrastructure of the telecommunications network 
Electric Network of Tcs (RET), with the aim of interconnecting and sharing connectivity nodes with the Internet, RedIRIS, i2CAT, and the "Catalan Scientific Ring". The project made progress in some parts of this rural territory but its development was also curtailed.

Finally, in 2016, Alt Urgell Fibra (2019) was created in the framework of a project promoted by the Provincial Council of Lleida and the Government of Catalonia with the aim of installing $1,500 \mathrm{~km}$ of fibre-optic cable and offering broadband access to every town and village in HP\&A (Diari El Segre, 2018). These initiatives, on a more local basis and in the smart village framework, have been successful to the extent that from eight municipalities in 2016, the number of connected villages has risen to more than forty in 2019. The stance of AltUrgell Fibra, a company that understands communications as a need in the territory, contrasts with the lack of interest in the big companies. The philosophy of the project is to create a joint network belonging to the users themselves and with maintenance costs and service quotas at fair prices. A foundation including all the shareholders in the business, all clients requesting to join, and the local administration has been created. The leading actors in the rural territory are engaged in this project, which is identified with that initiated by the ENRD group.

Local social services, health facilities, local administration, energy sources, the cultural and tourist domains, and all HP\&A commercial activities in the digital field have been installed in digital platforms that might be defined as a rural digital hub. Nevertheless, one of the most innovative contributions of HP\&A in the digital area is transport on demand (Gurrera, 1988). In 1991 an agreement was signed between the Alt Urgell Regional Council and the Transport Department of the Government of Catalonia in order, first, to study mobility problems of inhabitants of small towns and villages and, second, to decide routes, stops, and timetables so that it would be possible to ask for a ride in advance. The form of transport is nine-seat taxis, and twice-weekly return trips are programmed for shopping and other tasks. Digital platforms are used with access through the Internet and mobile or analogue phones. This means economic saving in a project that facilitates movement of the population, especially people who do not own their own vehicle or drive (Consell Comarcal de l'Alt Urgell, 2019). The total number of services per year in Alt Urgell district is presently 10,000 with an average of 6.3 passengers per trip for a population of some 6,000 inhabitants living outside the main road axis of the valley bounded by the Segre and Valira rivers. The service is presently being extended to other regions of HP\&A (Regió 7, 2019).

The BCN Smart Rural ${ }^{18}$ is an important initiative of development of the non-metropolitan territory because it could be an example for other rural areas. It was created by The Diputació de Barcelona, jointly with the Forest Technology Center of Catalonia, the Association of Rural Initiatives of Catalonia (ARCA), the Local Action Groups created with the support of the Feader funds and the consortia and the agencies of economic development that they work in the territory. BCN Smart Rural is a specialization and territorial competitiveness project (PECT) framed in the ERDF 2014-2020 operational program promoted by the European Union, which is based on a green and circular economy, of a local nature and that it must bring both economic, social and environmental benefits to small municipalities of the non-metropolitan area

It is also important to note the use of drones in administration of the territory. The company Mountains Tech uses planes and drones for forestry management, monitoring snowpack levels, and work related with ski stations. It is now taking part in a European project for the use of drones in the mountain economy (Heraldo de Aragón, 26 November 2018), working with the Pyrenean Business School association and the technological company HEMAV, ${ }^{19}$ which is a pioneer in drone development.

The smart rural area and/or smart villages have been introduced into HP\&A and other mountain regions, thus bringing into being a digital territory where barriers to localisation of production and service activities - which, previously, could only be based in urban and metropolitan areas- are now being eliminated. The trend of digitising territories, now extending throughout Europe, has been studied and promoted by the ENRD group (Hess, 2018).

\footnotetext{
18 https://www.diba.cat/web/sala-de-premsa/-/bcn-smart-rural-una-iniciativa-de-desenvolupament-del-territori-no-metropolita

$19 \mathrm{https} / /$ hemav.com/hemav/quienes-somos/
} 


\section{Discussion and Conclusions}

Peripheral rural areas have been losing population as a result of the abandonment of agricultural production. However, the incorporation of ICTs together with innovative approaches in both production and services offered in the zone has made it possible to engage in activities producing added value while still being compatible with the environment and the quality of the landscape. The productive, agrarian, and industrial network, and distribution and service activities are bolstered by the comparative advantage of innovation, spatial loyalty among the actors, embeddedness in the territory, ICT's, and environmental sustainability.

In the Catalan Pyrenees a digital hub with origins in four significant endeavours is now expanding: first, computerisation and innovation in dairy farms, which is closely linked with the technological evolution of the Cooperativa de Cadí (1980s); second, use of ICTs in strategic services like transport on demand and access to energy sources (1990s); third, localisation of companies producing fabrics for sports clothing and incorporating intelligent services which can be operated at the global level from the local situation thanks to the use of ICTs (2000s); and fourth, the extension of fibre-optic cable throughout the Catalan Pyrenees to facilitate the use of the Internet and digital platforms offering access to services (2010s).

In innovative enterprises and concerning their relation with the HP\&A as a whole, conclusions expressed by entrepreneurs of the zone attending the first "HP\&A Economic Congress" (2009) signalled a lack of entrepreneurial and innovative spirit. Although there were some very positive isolated experiences, they did not identify HP\&A as a particularly attractive zone for new innovative enterprises and consider that among the challenges that must necessarily be overcome if nodes attracting businesses are to be established: (1) Having the same telecommunications facilities in all areas of HP\&A as those in urban areas. (2) Although they are users of e-commerce and can appreciate its benefits, entrepreneurs have a "traditional" mentality and prefer to do business face-to-face rather than online. (3) Development initiatives have been individual and there is an absence of joint policy and territorial strategies. (4) Companies of the HP\&A have business relations mainly with other companies in the territory. (5) Finally, although there are individual initiatives, there is a need for public institutions that would make it possible to establish an environment that would be conducive to businesses and job creation for skilled workers in such a way that they would attract new highquality enterprises.

It could be concluded about the effects of introducing ICTs (Vera et al., 2011, Tulla et al., 2009) into companies and farms located in the Catalan Pyrenees, that:

a) Some competitive economic activities have made progress on the periphery of large urban areas since they do not need the economies of agglomeration.

b) Most of these companies are characterised by generating added value that enables them to compete with other simpler companies with lower production costs.

c) There is an increasingly greater need for any possibility of cooperation among companies from the same sector or with others engaged in different phases of creation and selling products. This involves the possibility of splitting the production and marketing processes, but also of building alliances among companies working in different phases.

d) ICTs are part of all phases of the process. Nevertheless, particularised attention, where the customer becomes more involved in requesting improvements in the design of products using social networks like Facebook and Twitter.

e) Localisation of these companies in places near high-quality landscape and natural protected areas gives rise to positive naturbanisation.

f) There can be no doubt that these companies contribute to local development in mountain areas and to the employment of women and young people, among other reasons because of their better skills in the use of constantly evolving ICTs.

g) Incorporation of drones and planes in territory management in general, but also working to improve the functioning of companies is a recent and noteworthy development. 


\section{Acknowledgments}

Funding has been received from the projects 2017 SGR - 343 (IP: M. Pallarès-Barberà) of the Government of Catalonia, and CSO 2015-65257-R (IP: A. Badia) of the Spanish Ministry of Economy and Competitiveness. We are grateful for the help of the experts interviewed.

\section{Academic references}

[1] Addison, T. \& Heshmati, A. (2003). The New Global Determinants of FDI Flows to Developing Countries: The Importance of ICT and Democratization [WIDER Discussion Papers No.2003/45). Helsinki: World Institute for Development Economics.

[2] Anderson, C. \& Bell, M. (2003). The Devil of Social Capital: a Dilemma of American Rural Sociology. In Cloke, P., ed., Country Visions (pp. 232-243). Harlow: Pearson.

[3] Atchoarena, D. \& Gasperini, L., eds. (2004). Education for Rural Development: Towards New Policy Responses. Rome: Food and Agriculture Organization of the United Nations.

[4] Barnes, T. J. (2003). The Place of Locational Analysis: A Selective and Interpretative History. Progress in Human Geography 27(1), 69-95. DOI: 10.1191/0309132503ph419oa.

[5] Barrachina, M. \& Tulla, A. F. (2010). Els canvis socioambientals al Pirineu català: la Vall Fosca com a escenari representatiu de les mutacions en les economies tradicionals de muntanya. Documents d'Anàlisi Geogràfica, 56(3), 557-572.

[6] Best, S. (1989). The Commodification of Reality and the Reality of Commodification: Jean Baudrillard and Post-Modernism. Current Perspectives in Social Theory 19, 23-51.

[7] Blanco, R. (2004). Catalunya i els factors de localització davant la nova economía. Nota d'Economia, 78, 115-134.

[8] Bock, B. B. (2010). Personal and Social Development of Women in Rural Areas of Europe. Brussels: European Parliament.

[9] Cheng, Yi-Li; Lin, Yuan-Hsu (2012). Performance Evaluation of Technological Innovation Capabilities in Uncertainty. Procedia - Social and Behavioral Sciences, 40, 287-314. DOI: 10.1016/j.sbspro.2012.03.193.

[10] Christ, J. P. (2009). New Economic Geography Reloaded: Localized Knowledge Spillovers and the Geography of Innovation [FZID Discussion Paper 01-2009]. Stuttgart: University of Hohenheim.

[11] Copus, A., Hall, C., Barnes, A., Dalton, G., Cook, P., Weingarten, P., Baum, S., Stange, H., Lindner, Ch., Hill, A., Eiden, G., McQuaid, R., Grieg, M. \& Johansson, M. (2006). Study on Employment in Rural Areas. Brussels: European Commission.

[12] Elbersen, B. (2005). Combining Nature Conservation and Residential Development in the Netherlands, England and Spain. Journal of Environmental Planning and Management, 48(1), 37-63. DOI: 10.1080/0964056042000308148.

[13] Esparcia, J. (2000). The LEADER Programme and the Rise of Rural Development in Spain. Sociologia Ruralis, 40 (2), 200-207. DOI: 10.1111/1467-9523.00142.

[14] Flora, C. B., Flora, J. L. \& Frey, S. (2008). Rural Communities: Legacy and Change, $3^{\text {rd }}$ edition. Boulder: Westview.

[15] Ganyet, J. \& Tulla, A. F., eds. (1993). Mab-6 Alt Pirineu (Urgellet-Baridà). Síntesis del Programa. Madrid: Ministerio de Obras Públicas y Transporte.

[16] Gascón, C. (2015). Cadí, 100 anys de cooperativa. La Seu d’Urgell: Societat Cooperativa del Cadí.

[17] Granovetter, M. (1985). Economic Action and Social Structure: the Problem of Embeddedness. American Journal of Sociology 91(3), 481-493. 
[18] Grau Trullàs, J. I. (2006). Modelo Catalán: Banda ancha rural de Catalunya. Sevilla: Tecnimap.

[19] Greenhut, M. L. (1956). Plant location in theory and in practice: the economics of space. Chapel Hill: University of North Carolina Press.

[20] Gurrera, J. (1988). El transport public de viatgers. Mab 6 Alt Pirineu. La Seu d'Urgell: Gráficas Fornesa.

[21] Hägerstrand, T. (1965). On Monte Carlo Simulation of Diffusion. European Journal of Sociology, 6(1), 43-67. DOI: 10.1017/S0003975600001132.

[22] Hartshorne, R. (1926). The significance of lake transportation to the grain traffic of Chicago. Economic Geography, 2(2), 274-291. DOI: 10.2307/140869.

[23] Hess, S., Kolosy, K., O'Hara, E., Paneva, V. \& Solo, P. (2018). Smart Villages Revitalising Rural Services. Luxembourg: Publ. Office of the EU.

[24] Hidalgo, A. Vizán, A. \& Torres, M. (2008). Los factores clave de la innovación tecnológica: claves de la competitividad empresarial. Dirección y Organización 36, 5-22.

[25] Ifinedo, P. (2011). An Empirical Analysis of Factors Influencing Internet/e-business Technologies Adoption by SMEs in Canada, Journal and International Technology and Decision Making 10(4), 19-28. DOI: 10.1142/S0219622011004543.

[26] Jordá-Borrella, R. M., López-Oterob, J. \& Contreras-Cabrerac, G. (2018). Factores de mayor incidencia en la adopción de innovaciones tic a escala de pais. Importancia de las relaciones directas e indirectas entre factores. In Sá Marques, T., Helder Santos \& Pilar Alonso, M., eds., VIII Jornadas de Geografía Económica: La Geografía de las Redes Económicas y la Geografía Económica en Rede (pp. 91-99). Porto: Universidade do Porto.

[27] Kelly, K. (1998). New Rules for the New Economy. New York: Viking.

[28] Kitchen, L. \& Marsden, T. (2009). Creating Sustainable Rural Development through Stimulating the Eco-Economy: Beyond the Eco-Economic Paradox? Sociologia Ruralis, 49(3), 273-94. DOI: 10.1111/j.1467-9523.2009.00489.x.

[29] Knox, P., Agnew, J. \& McCarthy, L. (2003). The Geography of the World Economy: An Introduction to Economic Geography. Oxford: Oxford University Press.

[30] Kock Exterckoter, R., Tulla, A. F. \& Azevedo, C. (2016). Análisis bibliométrico del concepto de resiliencia aplicado al desarrollo regional. Documents d'Anàlisi Geogràfica 62(2), 275298.

[31] Landry, R., Amara, N. \& Lamari, M. (2002). Does Social Capital Determine Innovation? To What Extent? Technological Forecasting and Social Change 69(7), 681-701. DOI: 10.1016/S0040-1625(01)00170-6.

[32] Laursen, K. \& Salter, A. (2006). Open for Innovation: The Role of Openness in Explaining Innovation Performance among UK Manufacturing Firms. Strategic Management Journal 27(2), 131-150. DOI: 10.1002/smj.507.

[33] Levin, R. C. \& Reiss, P. C. (1988). Cost-reducing and Demand-creating R\&D with Spillovers. Rand Journal of Economics 19(4), 538-556. DOI: 10.2307/2555456.

[34] Loo, S. van der, Chen, L., Edwards, P., Holden, J. A., Karamperidis, M. J., Kollingbaum, A. C., Marqui, J. D., Nelson, T. J., Norman, M., Piecyk, M. \& Pignotti, E. (2015). Development of a Digital Tool to Overcome the Challenges of Rural Food SMEs. Scottish Geographical Journal 131(3-4), 212-219. DOI: 10.1080/14702541.2014.994673.

[35] Lundvall, B. (1992). National Innovation System of Innovation: Towards a Theory of Innovation and Interactive Learning. London: Printer Publisher.

[36] Malecki, E. J. (2003). Digital development in rural areas: potentials and pitfalls. Journal of Rural Studies 19(2), 201-214. DOI: 10.1016/S0743-0167(02)00068-2. 
[37] Mateu i Llevadot, X. (1988). El marc local I la prestació dels serveis municipals a l'àrea MAB-6 ALT PIRINEU. Documents d'Anàlisi Geogràfica 12, 163-177.

[38] Mármol Cartañá, C. (2016). Muntanyes de formatge. Transformacions productives I patrimonialització a l'Urgellet i el Baridà. Barcelona: Generalitat de Catalunya.

[39] Mayer-Schönberger, V. \& Cukier, K. (2013). Big data: A Revolution That Will Transform How We Live, Work, and Think. New York: Houghton Mifflin Harcourt.

[40] Nieto-Antolín, M. \& González-Álvarez, N. (2011). Estructura de la industria, entorno institucional y actividad innovadora en la empresa industrial Española. ICE: Revista de Economía 860, 57-71.

[41] Noguera Tur, J. \& Copus, A. (2016). A Proposal for Classification of Non-Urban Regions in the European Union. Cuadernos Geográficos 55(1), 92-124.

[42] Pallarès-Barberà, M. (2003). Geografia econòmica i localització industrial. Documents d'Anàlisi Geogràfica 42, 171-182.

[43] Pallarès-Barberà, M., Tulla, A. F. \& Vera, A. (2004). Spatial Loyalty and Territorial Embeddedness in the Multi-Sector Clustering of the Berguedà Region in Catalonia (Spain). Geoforum 35(5), 635-649. DOI: 10.1016/j.geoforum.2004.03.004.

[44] Pallarès-Blanch, M., Tulla, A. F. \& Vera, A. (2015). Environmental Capital and Women's Entrepreneurship: A Sustainable Local Development Approach. Carpathian Journal of Earth and Environmental Sciences, 10(3), 133-146.

[45] Paneva, V., Soto, P., Zapres, K., Nieto, E., Coto, M., Eldridge, J., Hess, S., Jonasson, Y., Kok, M., Kolosy, K., Mueller, T., Norrby, T., Porta, M., Rinne, P. \& Slee, B. (2018) Digital and Social Innovation in Rural Services. Luxembourg: Publication Office of the EU.

[46] Perkins, H. C. (2006). Commodification: Re-resourcing Rural Areas. In Cloke, P., Marsden, T. \& Mooney, P., eds., Handbook of Rural Studies (pp. 243-257). London: Sage.

[47] Philip, L. \& Williams, F. (2019). Remote rural home based businesses and digital inequalities: Understanding needs and expectations in a digitally underserved community. Journal of Rural Studies 68, 306-318. DOI: 10.1016/j.jrurstud.2018.09.011.

[48] Piore, M. J. \& Sabel, C. F. (1984). The Second Industrial Divide. Possibilities for Prosperity. New York: Basic Books.

[49] Ploeg, J. D. van, Renting, H., Brunori, G., Knickel, K., Mannion, J., Marsden, T., De Roest, K., Sevilla-Guzmán, E. \& Ventura, F. (2000). Rural Development: From Practices and Policies towards Theory. Sociologia Ruralis 40(4), 391-408. DOI: 10.1111/14679523.00156.

[50] Prados, M. J. (2009). Conceptual and Methodological Framework of Naturbanization. In Prados, M. J., ed., Naturbanization: New Identities and Processes for Rural-Natural Areas (pp. 11-28). London: Taylor \& Francis.

[51] Pred, A. (1967). Behaviour and location: foundations for a geographic and dynamic location theory, Part I. The Royal University of Lund.

[52] Pred, A. (1969). Behaviour and location: foundations for a geographic and dynamic location theory, Part II. The Royal University of Lund.

[53] Rawstron, E. M. (1958). Three principles of industrial location. Transactions of the Institute of British Geographers 25, 132-142. DOI: 10.2307/621183.

[54] Ray, C. (1999). Endogenous Development in the Era of Reflexive Modernity. Journal of Rural Studies 15(3), 257-67. DOI: 10.1016/S0743-0167(98)00072-2.

[55] Renner, G. T. (1947). Geography of Industrial Localization. Economic Geography 23(3), 167-189.

[56] Renner, G. T. (1950). Some Principles and Laws of Economic Geography. Journal of Geography 49(1), 14-22. DOI: 10.1080/00221345008982427. 
[57] Roberts, E., Anderson, B. A., Skerratt, S. \& Farrington, J. (2017). A review of the ruraldigital policy agenda from a community resilience perspective. Journal of Rural Studies 54, 372-385. DOI: 10.1016/j.jrurstud.2016.03.001.

[58] Sabel, C. (1989). Flexible Specialization and Re-emergence of Regional Economies. In Hirst, P. \& Zeitlin, P., eds., Reversing Industrial Decline? Industrial Structure and Policy in Britain and Her Competitors (pp. 17-71). Oxford: Beig Publishers.

[59] Salemink, K., Strijker, D. \& Bosworth, G. (2017). Rural development in the digital age: A systematic literature review on unequal ICT availability, adoption, and use in rural areas. Journal of Rural Studies 54, 360-371. DOI: 10.1016/j.jrurstud.2015.09.001.

[60] Smith, D. M. (1966). A theoretical framework for geographical studies of industrial location. Economic Geography 42(2), 95-113. DOI: 10.2307/141912.

[61] Solana, A. M. (2008). El encanto de lo rural, los términos del debate sobre la emigración hacia áreas rurales desde la geografía británica y las contribuciones españolas. Un estado de la cuestión. Revista bibliográfica de Geografía y ciencias sociales 13(776).

[62] Solé, A., Guirado, C. \& Solana, A. M. (2012). Cambios en la dinámica demográfica y migratoria del Pirineo catalán. Análisis sociolaboral de la población extranjera. AGER, Revista de estudios sobre despoblación y desarrollo rural 12, 51-90.

[63] Taylor, P. J. (1989). The Error of Developmentalism in Human Geography. In Gregory, D. \& Walford, R., eds., Horizons in Human Geography (pp. 303-319). London: Macmillan. DOI: 10.1007/978-1-349-19839-9_16.

[64] Tirado, J. G. (2017). La funcionalidad turística de los espacios rurales: conceptualización y factores de desarrollo. Cuadernos Geográficos 56(3), 312-332.

[65] Tulla, A. F. (1983). El modelo de difusión de T. Hägestrand. Una aplicación a la ganadería del Pirineo Catalán. Documents d'Anàlisi Geogràfica 2, 69-160.

[66] Tulla, A. F., Pallarès-Barberà, M. \& Vera, A. (2009). Naturbanization and Local Development in the Mountain areas of Catalan Pyrenees. In Prados, J. M., ed., Naturbanization: New Identities and Processes for Rural-Natural Areas (pp. 75-92). London: Taylor \& Francis.

[67] Tulla, A. F., Stoica, I. V., Pallarès-Blanch, M. \& Zamfir, D. (2017). Can Naturbanization Promote Environmentally Friendly Built-Up Areas? A Comparison between Cadí-Moixeró (Catalonia, Spain) and Comana (Romania) Natural Parks. European Countryside 9(4), 679-708. DOI: 10.1515/euco-2017-0039.

[68] Tulla, A. F., Vera, A., Valldeperas, N. \& Guirado, C. (2018). Social Return and Economic Viability of Social Farming in Catalonia: A Case-Study Analysis. European Countryside 10(3), 398-428. DOI: 10.2478/euco-2018-0023.

[69] Tulla, A. F. (2019). Sustainable Rural Development Requires Value-Added Activities Linked with Comparative Advantage: The Case of the Catalan Pyrenees. European Countryside 11(2), 229-256. DOI: 10.2478/euco-2019-0012.

[70] Ventura, F., Milone, P. \& Van der Ploeg, J. D. (2010). Understanding Rural Development Dynamics. In Milone, P. \& Ventura, F., eds., Networking the Rural. The Future of Green Regions in Europe (pp. 1-29). Assen: Royal Van Gorcum.

[71] Vera, A., Badia, A. \& Pallarès-Barberà, M. (2003). La adopción de internet en la red de empresas y la percepción de la nueva economía en comarcas semi-remotas de tradición industrial de Catalunya. Boletín de la Asociación de Geógrafos Españoles 36, 129-147.

[72] Vera, A., Badia, A. \& Tulla, A. F. (2011). Desarrollo local en el Pirineo Catalán: impulso económico y sostenible del territorio. Finisterra 92, 5-23.

[73] Wilson, G. A. (2007). Multifunctional Agriculture: A Transition Theory Perspective. Wallingford: $C A B$ international. 
[74] Alt Urgell Fibra Óptica (2019). https://www.alturgellfibra.cat/index.php/clients/.

[75] Action for Smart Villages (2018). https://ec.europa.eu/agriculture/sites/agriculture/files/ruraldevelopment-2014-2020/looking-ahead/rur-dev-small-villages_en.pdf.

[76] Diari El Segre (2018).

https://www.segre.com/es/noticias/lleida/2018/09/07/acuerdo_para_instalar_500_de_fibra_ optica_dar_banda_ancha_cada_pueblo_55592_1092.html.

[77] Dones i Món Rural: Neix l'Associació de Dones del Món Rural, Pageses i Ramaderes (2018). https://www.viurealspirineus.cat/articulo/associacions/neix-I-associacio-dones-monrural-pageses-i-ramaderes-catalunya/20190121132359013252.html.

[78] Dones ramaderes a Catalunya (2018). https://www.facebook.com/pg/Ramaderescat787838001413853/posts/?ref=page_internal.

[79] ENRD Publications (2018). https://enrd.ec.europa.eu and http://bookdhop.europa.eu.

[80] Fundació Observatori per la Societat de la Informació de Catalunya (2004). Encuesta sobre la penetración de las tecnologías de la Información y de la Comunicación en las empresas de 10 o más trabajadores de Catalunya (2003). Generalitat de Catalunya.

[81] Fundació Observatori per la Societat de la Informació de Catalunya (2010). Encuesta sobre el uso de las Tecnologías de la Información y la Comunicación (TIC) y del comercio electrónico en las empresas de Catalunya 2005-2009. Generalitat de Catalunya.

[82] Government of Catalonia (2017). Baròmetre de la Innovació a Catalunya 2014 a 2017. Barcelona: Generalitat de Catalunya.

[83] Ganaderas en Red (2017). https://www.facebook.com/GanaderasenRed/.

[84] Grifone - Tèxtil La Seu S.A. http://www.grifone.eu (Consulta 15/05/2012).

[85] Grifone, nueva etapa (2018). https://www.modaes.es/empresa/grifone-nueva-etapa-dosex-directivos-de-la-empresa-compran-la-marca-para-convertirla-en-el-nuevo-moncler.html.

[86] Heraldo de Aragón (2018).

https://www.heraldo.es/noticias/aragon/huesca/2018/11/26/benasque-activa-proyectoeuropeo-para-uso-drones-economia-montana-1279732-2261127.html (consulted 14/03/2019).

[87] Idescat (2012). Uso de TIC y del comercio electrónico en las empresas. http://www.idescat.cat/es/economia/tice.html (Consulta 15/05/2012).

[88] Institut per al desenvolupament I la promoció de l'Alt Pirineu i Aran (2009). Primeres jornades econòmiques de l'Alt Pirineu i Aran. L'economia pirinenca avui: oportunitats en temps de crisi. Talarn -3 de diciembre de 2009.

[89] Instituto de Estadística de España (2016a). Encuesta sobre el uso de las Tecnologías de la Información y las Comunicaciones (ICT). Madrid: INE.

[90] Instituto de Estadística de España (2016b). Comercio electrónico en las empresas para el año 2016. Madrid: INE.

[91] Informe Brundtland (1987) Informe de la Comisión Mundial sobre el Medio Ambiente y el Desarrollo. Asamblea General de las Naciones Unidas, 4-08-1987.

[92] Oficina de marques del Principat d'Andorra. Bases de dades OMPA (2002). http://www.ompa.ad (Consulta 15/05/2012).

[93] Ogilvy in the Seu d'Urgell (2018). https://www.ara.cat/economia/Ogilvy-installa-Urgellcontracta-desenvolupadors_0_2070992898.html.

[94] Rural Development Programmes (2018). https://enrd.ec.europa.eu/policy-in-action/ruraldevelopment-policy-figures/rdp-summaries_en. 
[95] Smart Villages (2018). https://enrd.ec.europa.eu/enrd-thematic-work/smart-andcompetitive-rural-areas_en.

[96] RuralNet (2003). https://www.computerworld.es/archive/ruralnet-dara-acceso-de-bandaancha-al-alto-pirineo-catalan. 